\title{
Keanekaragaman Mikrob Fungsional Rizosfer Nanas dengan Berbagai Tingkat Produktivitas
}

\section{(The Diversity of Soil Functional Microbes in Pineapple Rhizosphere on Various Levels of Productivity)}

\author{
Aditya Dyah Utami ${ }^{1 *}$, Suryo Wiyono ${ }^{2}$, Rahayu Widyastuti ${ }^{3}$, Priyo Cahyono ${ }^{4}$
}

(Diterima Agustus 2018/Disetujui Juli 2020)

\begin{abstract}
ABSTRAK
Mikrob fungsional yang berperan penting dalam transformasi hara dan pengendalian penyakit juga memengaruhi pertumbuhan dan perkembangan tanaman. Akan tetapi, peran mikrob tersebut belum banyak diteliti untuk mendukung keberlanjutan produktivitas nanas. Tujuan penelitian ini adalah mengkaji kelimpahan dan keanekaragaman mikrob fungsional tanah pada fase pertumbuhan yang berbeda, yaitu vegetatif dan generatif pada berbagai tingkat produktivitas nanas. Tahapan penelitian meliputi pengambilan contoh tanah rizosfer, pengamatan insidensi penyakit, dan isolasi mikrob fungsional, yaitu Azotobacter, bakteri pelarut fosfat, bakteri pelarut kalium, bakteri penghasil antibiotik, bakteri penghasil IAA, dan bakteri kitinolitik. Metode pengambilan contoh tanah adalah simple randomized sampling pada 6 lokasi dengan luasan setiap lokasi \pm 5 ha dengan kedalaman $20 \mathrm{~cm}$. Rizosfer diambil dari tanaman yang tumbuh pada lahan dengan produktivitas tinggi $(>60 \mathrm{ton} / \mathrm{ha})$ dan produktivitas rendah $(<60$ ton/ha) baik pada fase vegetatif maupun pada fase generatif. Hasil penelitian menunjukkan bahwa kelimpahan bakteri pelarut kalium, bakteri kitinolitik, dan bakteri penghasil IAA lebih tinggi pada fase generatif. Kelimpahan Azotobacter, bakteri pelarut fosfat, dan bakteri penghasil antibiotik lebih tinggi pada fase vegetatif, baik pada produktivitas tanaman tinggi maupun rendah. Total mikrob ditemukan lebih tinggi di lahan dengan produktivitas tanaman yang tinggi dibandingkan dengan lahan dengan produktivitas rendah. Kelimpahan bakteri penghasil IAA dan bakteri kitinolitik berkorelasi negatif dengan serangan patogen Erwinia chrysanthemi dan Phytophthora cinnamomi.
\end{abstract}

Kata kunci: bakteri kitinolitik, IAA, fase pertumbuhan, penyakit nanas

\section{ABSTRACT}

Functional microbes of rhizosphere play important roles in nutrient transformation and controlling disease as well as in supporting plant growth and development. However, there is no study on the role of functional microbes on pineapple productivity. The purpose of this study was to investigate the abundance and diversity of soil functional microbes at different growth phases at two levels of productivity and their correlations to disease incidence. The research process included sampling of pineapple rhizospheric soil from vegetative and generative phases pineapples at low and high plant productivity sites, observations of disease incidence, and isolations of functional microbes. Functional groups of bacteria were Azotobacter, phosphate-solubilizing bacteria, potassium-solubilizing bacteria, antibiotics-producing bacteria, IAA-producing bacteria, and chitinolytic bacteria. The soil sampling method was simple randomized sampling at 6 locations with an area of each location \pm 5 ha with a depth of $20 \mathrm{~cm}$. Rhizosphere were taken in plants grown in high productivity area (>60tons/ha) and low productivity area ( $<60$ tons/ha) in vegetative and generative phases. The results showed that potassium-solubilizing bacteria, chitinolytic bacteria, and IAAproducing bacteria were more abundant during the generative phase compared to those during vegetative phase. While Azotobacter, phosphate-solubilizing bacteria, and antibiotic-producing bacteria were more predominant during vegetative phase at various crop productivy. Total density of microbes was higher in soil with high crop productivity than that in soil with low crop productivity. The abundance of chitinolytic bacteria and IAA-producing bacteria had negative correlation with disease caused by Erwinia chrysanthemi and Phytophthora cinnamomi.

Keywords: chitinolytic bacteria, growth phase, IAA, pineapple disease

${ }^{1}$ Akademi Komunitas Perkebunan Yogyakarta, Depok, Sleman, Yogyakarta 55281

2 Departemen Proteksi Tanaman, Fakultas Pertanian, Institut Pertanian Bogor, Kampus IPB Darmaga, Bogor 16680

3 Departemen IImu Tanah dan Sumberdaya Lahan, Fakultas Pertanian, Institut Pertanian Bogor, Kampus IPB Darmaga, Bogor 16680

4 PT Great Giant Food, Jalan Lintas Timur Sumatera, KM 77 Arah Menggala, Terbanggi Besar, Lampung Tengah, Kabupaten Lampung Tengah, Lampung 34163

* Penulis Korespondensi:

Email: adityadyahutami15@gmail.com

\section{PENDAHULUAN}

Nanas (Ananas comosus) merupakan tanaman hortikultura tropis yang buahnya banyak manfaat karena kandungan gizi berupa kalsium, potassium, vitamin, bromealin, dan serat (Harahap \& Nusyirwan 2014; Adam et al. 2016; Ramli et al. 2018). Nanas tidak hanya dikonsumsi buahnya, tetapi bagian tanaman lainnya, seperti daun dan limbahnya dapat dimanfaatkan. Manfaat nanas yang tinggi menyebabkan 
nanas diminati masyarakat internasional sehingga dilakukan pengembangan budi daya pada skala perkebunan.

Produktivitas nanas dipengaruhi oleh berbagai faktor, seperti serangan patogen dan kualitas tanah di lahan perkebunan. Upaya yang dapat dilakukan untuk meningkatkan produktivitas nanas salah satunya adalah melalui kajian sifat biologi tanah. Sifat biologi sangat berkaitan dengan sifat-sifat tanah yang lain, yaitu sifat fisik dan kimia. Kajian biologi tanah dapat dilakukan melalui eksplorasi mikrob rizosfer. Aktivitas mikrob rizosfer sangat dipengaruhi oleh fase pertumbuhan tanaman. Karena fase pertumbuhan tanaman menghasilkan komposisi eksudat akar yang berbeda sehingga kelimpahan dan keanekaragamannya juga berbeda. Keadaan kimia dan biologi tersebut berpengaruh kuat pada produktivitas tanaman.

Penelitian mengenai mikrob di rizosfer nanas telah dilakukan dan menunjukkan bahwa terdapat beberapa mikrob, seperti Fusarium spp., Burkholderia sp., Azospirillum amazonense, serta Azospirillum lipoferum (Weber et al. 2009). Mikrob tersebut menghasilkan asam-asam organik dan hormon zat pengatur tumbuh yang dapat dimanfaatkan oleh tanaman untuk membantu pertumbuhannya (Moreno-Salazar et al. 2020). Akan tetapi, penelitian tersebut hanya terfokus pada identifikasi individual mikrob dan belum ada penggalian informasi mengenai komunitas mikrob fungsional di rizosfer nanas.

Komunitas mikrob fungsional perlu diketahui karena memiliki peranan penting, baik dalam ketersediaan hara, pengendalian penyakit, dan produksi senyawasenyawa yang menunjang pertumbuhan dan perkembangan tanaman (Al-Maliki \& Ebreesum 2020; Fraser et al. 2016; Jha \& Saraf 2015). Selain itu, keanekaragaman dan kelimpahan mikrob tanah sangat terkait dengan produktivitas lahan (Schnitzer et al. 2011). Pengetahuan tentang kelimpahan dan keanekaragaman mikrob penting untuk menentukan arah pengelolaan suatu lahan. Oleh karena itu, diperlukan suatu penelitian untuk mengkaji komunitas mikrob fungsional di rizosfer nanas. Kajian dilakukan pada fase pertumbuhan tanaman nanas yang berbeda (vegetatif dan generatif) serta pada produktivitas yang tinggi dan rendah. Tujuan penelitian ini adalah mengamati kelimpahan dan keanekaragaman mikrob fungsional tanah pada fase pertumbuhan yang berbeda di berbagai tingkat produktivitas tanaman serta hubungannya dengan insidensi penyakit nanas.

\section{METODE PENELITIAN}

\section{Tempat dan Waktu Penelitian}

Pengambilan contoh tanah dilaksanakan di lahan perkebunan nanas PT Great Giant Pineapple, Terbanggi Besar, Lampung Tengah. Analisis biologi tanah dilaksanakan di Laboratorium CV Wish Indonesia Dramaga Bogor, Laboratorium Mikrobiologi,
Departemen Biologi, Fakultas Matematika dan IImu Pengetahuan Alam dan Laboratorium Biologi Tanah, Departemen IImu Tanah dan Sumberdaya Lahan, Fakultas Pertanian, Institut Pertanian Bogor.

\section{Alat dan Bahan Penelitian}

Bahan-bahan yang digunakan dalam penelitian ini adalah contoh tanah rizosfer nanas, media nutrient Agar (NA), tryptic soy broth (TSB), media potato dextrose agar (PDA), media alexandrov, media pikovskaya, media nitrogen-free mannitol (NFM), dan bahan kimia lain untuk analisis biologi tanah. Alat-alat yang digunakan terdiri atas peralatan lapangan untuk pengambilan contoh tanah dan alat-alat laboratorium untuk analisis biologi tanah.

\section{Pelaksanaan Penelitian \\ - Pengambilan contoh tanah}

Pengambilan contoh tanah dilakukan pada rizosfer nanas yang ditentukan berdasarkan fase pertumbuhan dan tingkat produktivitas tanaman. Fase pertumbuhan adalah fase vegetatif dan fase generatif. Tingkat produktivitas tanaman yang digunakan adalah produktivitas kategori tinggi (>60 ton/ha) dan rendah $(<60$ ton/ha). Contoh tanah diambil pada pertanaman first crop, yaitu tanaman yang belum panen pertama dengan varietas GP1.

Pada setiap lahan dengan tingkat produktivitas tanaman yang berbeda, pengambilan contoh tanah dilakukan pada fase pertumbuhan tanaman vegetatif (nanas umur 7-9 bulan) dan generatif (nanas umur 10-12 bulan) yang diambil pada 6 lokasi dengan luasan setiap lokasi \pm 5 ha. Metode pengambilan contoh tanah adalah simple randomized sampling. Pada setiap lokasi, contoh tanah diambil dari 9 titik tanaman. Lokasi yang dijadikan titik pengambilan contoh tanah dibersihkan dari serasah tanaman. Tanah digali hingga kedalaman $20 \mathrm{~cm}$ dan terlihat perakaran tanaman. Contoh tanah yang diambil adalah bagian rizosfer. Contoh tanah dikompositkan, diambil $500 \mathrm{~g}$, dan dimasukkan ke dalam cool box.

\section{- Pengamatan penyakit nanas}

Penyakit yang diamati di lapang ialah penyakit layu/Pineapple Mealybug Wilt-associated Virus (PMWaV), busuk akar yang disebabkan oleh Phytophthora cinnamomi, dan penyakit busuk buah yang disebabkan oleh Erwinia chrysanthemi. Pengamatan insidensi penyakit dilakukan pada 60 contoh tanaman pada setiap titik pengambilan contoh tanah dan mengamati tanaman yang memperlihatkan gejala serangan penyakit. Rumus untuk perhitungan insidensi penyakit adalah sebagai berikut.

$$
\text { Insidensi penyakit }(\%)=\frac{n}{N} \times 100 \%
$$

Keterangan:

$\mathrm{n}=$ Jumlah unit tanaman terinfeksi

$\mathrm{N}=$ Total jumlah unit tanaman yang diamati 


\section{Eksplorasi Mikrob Rizosfer Nanas}

- Total mikrob, karakterisasi morfologi, dan pemurnian isolat

Sebanyak $5 \mathrm{~g}$ contoh tanah ditimbang dan dimasukkan ke erlenmeyer yang berisi larutan fisiologis steril sebanyak $45 \mathrm{~mL}$. Selanjutnya, campuran dihomogenkan menggunakan shaker dengan kecepatan 120 rpm selama 30 menit. Suspensi tersebut diambil sebanyak $1 \mathrm{~mL}$ larutan dan dimasukkan ke dalam tabung reaksi yang berisi larutan fisiologis $9 \mathrm{~mL}$. Pengenceran dilakukan sampai tingkat pengenceran $10^{-5}$. Dari tingkat pengenceran $10^{-2}$ dan $10^{-3}$ masingmasing diambil $0,1 \mathrm{~mL}$ suspensi dan dituang ke media PDA dalam cawan petri untuk isolasi cendawan. Sebanyak $0,1 \mathrm{~mL}$ larutan suspensi dari tingkat pengenceran $10^{-3}$ dan $10^{-4}$ dituang ke media NA dalam cawan petri steril untuk isolasi bakteri (metode spread plate). Isolasi cendawan dan bakteri pada masingmasing pengenceran tersebut dilakukan dalam dua ulangan. Selanjutnya, diinkubasi selama 72 jam dalam suhu $28-31^{\circ} \mathrm{C}$. Isolat cendawan dan bakteri yang tumbuh dihitung jumlah koloninya dan dikarakterisasi morfologi awal berdasarkan warna, bentuk, ukuran, elevasi, dan margin. Kemudian, setiap isolat dimurnikan dengan metode quadran-streak plate untuk mendapatkan koloni tunggal bakteri dan dikarakterisasi morfologi pada koloni tunggal bakteri berdasarkan warna, bentuk, ukuran, elevasi, dan margin. Selanjutnya, isolat dipindahkan ke media agar miring NA dalam tabung reaksi untuk disimpan dan selanjutnya dilakukan uji antibiosis dengan Rhizoctonia solani dan diuji kemampuan menghasilkan Indole Acetic Acid (IAA).

Total mikrob $\left(\mathrm{cfu} \mathrm{g}^{-1}\right)=($ jumlah koloni $) \times 10 \times \mathrm{fp} \times \frac{\mathrm{BB}}{\mathrm{BKM}}$

Keterangan:

$\mathrm{fp} \quad=$ Faktor pengenceran

$\mathrm{bb}=$ Bobot basah

$\mathrm{bkm}=$ Bobot kering mutlak

\section{Kelimpahan Mikrob Fungsional}

Mikrob fungsional tanah yang dianalisis adalah bakteri pelarut kalium, bakteri penambat $\mathrm{N}_{2}$ (Azotobacter), bakteri pelarut fosfat, bakteri kitinolitik, bakteri penghasil antibiotik, dan bakteri penghasil IAA yang masing-masing menggunakan media, yaitu media Alexandrov, media NFM, media Pikovskaya, media TSB yang ditambahkan koloidal kitin dan triptofan. Sebanyak $5 \mathrm{~g}$ contoh tanah rizosfer nanas yang akan diisolasi, diencerkan pada larutan fisiologis hingga pengenceran $10^{-4}$. Pengenceran yang dilakukan untuk mengisolasi Azotobacter adalah $10^{-3}$ dan 10 ${ }^{4}$, dan untuk mengisolasi bakteri pelarut kalium, bakteri pelarut fosfat, dan bakteri kitinolitik adalah $10^{-4}$ dan 10 ${ }^{5}$ masing-masing dua ulangan. Metode isolasi yang digunakan adalah spread plate. Kemudian diinkubasi selama 72 jam sampai 168 jam dalam suhu $28-31^{\circ} \mathrm{C}$.

Analisis bakteri penghasil IAA dilakukan dengan menggunakan media TSB. Isolat bakteri yang disimpan dalam media agar miring NA diambil sebanyak 1 lup menggunakan jarum ose kemudian dimasukkan ke media TSB $5 \mathrm{~mL}$. Campuran diinkubasi sambil dilakukan pengadukan selama 24 jam. Selanjutnya, diambil $2 \mathrm{~mL}$ suspensi kemudian dimasukkan ke dalam tabung eppendorf untuk dicentrifuge pada suhu $4^{\circ} \mathrm{C}$ dengan kecepatan $11.000 \mathrm{rpm}$ selama 15 menit. Suspensi cair sebanyak $1 \mathrm{~mL}$ dimasukkan ke tabung reaksi dan ditetesi reagen salkowski sebanyak $2 \mathrm{~mL}$, kemudian diinkubasi selama 30 menit pada ruang gelap, dan selanjutnya diuji menggunakan spektrofotomer dengan panjang gelombang $530 \mathrm{~nm}$. Kemudian dilakukan perhitungan persentase bakteri yang mampu menghasilkan IAA dari total isolat bakteri yang diuji.

Uji antibiosis secara in vitro dilakukan pada media PDA dalam cawan petri dengan metode uji ganda (dual culture). Isolat bakteri sebanyak 1 lup inokulan digoreskan pada media PDA yang diberi jarak $2 \mathrm{~cm}$ dari patogen. Patogen yang digunakan dalam uji ini adalah Rhizoctonia solani. Mikrob diinkubasi selama 72-168 jam pada suhu $28-31^{\circ} \mathrm{C}$ dan dilakukan pengamatan pembentukan zona bening yang berarti bakteri positif menghasilkan antibiotik. Kemudian dilakukan perhitungan persentase bakteri penghasil antibiotik dari total isolat yang diuji.

\section{Analisis Data}

Data penelitian yang didapat kemudian dianalisis menggunakan software Microsoft Excel untuk mendeskripsikan kelimpahan mikrob dan mikrob fungsional, dan insidensi penyakit tanaman. Analisis ANOVA dilakukan untuk menguji kelimpahan mikrob pada fase pertumbuhan dan tingkat produktivitas tanaman. Hubungan mikrob fungsional dengan patogen diuji korelasi menggunakan software Minitab 16.

\section{HASIL DAN PEMBAHASAN}

\section{Kelimpahan Mikrob Tanah pada Fase Pertumbuhan Tanaman}

Kelimpahan dan keanekaragaman mikrob rizosfer dipengaruhi oleh berbagai hal, salah satunya fase pertumbuhan tanaman. Fase pertumbuhan tanaman akan mensekresikan eksudat akar yang berbeda. Eksudat akar tersebut dimanfaatkan sebagai sumber nutrisi mikrob. Hasil eksplorasi mikrob di rizosfer nanas menunjukkan bahwa kelimpahan mikrob total, yaitu cendawan (Gambar 1a) dan bakteri (Gambar 1b) berbeda antara fase vegetatif dan generatif tanaman. Kelimpahan cendawan dan bakteri pada fase generatif lebih tinggi dibandingkan pada fase vegetatif tanaman, tetapi tidak berbeda nyata pada kedua fase tersebut. Seperti halnya yang dilaporkan oleh beberapa peneliti bahwa kelimpahan mikrob rizosfer lebih banyak ditemukan pada saat tanaman mengalami fase generatif. Hal ini dikarenakan sekresi gula sederhana dan asam organik sebagai substrat respirasi mikrob lebih banyak pada fase generative sehingga memengaruhi aktivitas mikrob rizosfer (Chen et al. 
2016; Shazad et al. 2015; Proctor \& He 2017; Campbell 1985).

Hasil eksplorasi mikrob fungsional rizosfer juga menunjukkan kelimpahan yang berbeda antara fase vegetatif dan fase generatif tanaman (Gambar 1c). Kelimpahan bakteri pelarut kalium lebih tinggi pada fase generatif dibandingkan dengan fase vegetatif tanaman dan keduanya berbeda nyata. Bakteri kitinolitik memiliki kelimpahan yang serupa, yaitu lebih tinggi pada fase generatif tanaman, tetapi keduanya tidak berbeda nyata. Kelimpahan bakteri pelarut kalium dan bakteri kitinolitik yang tinggi pada fase generatif tanaman diduga berkaitan dengan asam organik dari eksudat akar yang disekresikan berperan menunjang aktivitasnya.

Akan tetapi, kelimpahan Azotobacter dan bakteri pelarut fosfat (Gambar 1c), menunjukkan hasil yang berbeda. Azotobacter kelimpahannya lebih tinggi pada fase vegetatif tanaman dan keduanya berbeda nyata. Azotobacter sebagai penambat $\mathrm{N}_{2}$ menurut Campbell (1985), membutuhkan asam amino dalam penambatan $\mathrm{N}_{2}$. Asam amino banyak disekresikan pada saat fotosintesis yang meningkat selama fase vegetatif tanaman. Sama halnya dengan Azotobacter, dari Gambar 1c menunjukkan bahwa bakteri pelarut fosfat lebih tinggi kelimpahannya pada fase vegetatif dibandingkan dengan pada fase generatif, tetapi keduanya tidak berbeda nyata. Kelimpahan bakteri pelarut fosfat yang tinggi pada fase vegetatif memengaruhi imobilisasi fosfat di dalam tanah. Fosfat yang cepat terimobilisasi sehingga peran bakteri pelarut fosfat sangat diperlukan agar fosfat tersedia bagi tanaman (Sobral et al. 2004).

\section{Kelimpahan Mikrob Tanah pada Berbagai Tingkat Produktivitas Tanaman}

Terdapat keterkaitan antara kelimpahan mikrob rizosfer dengan produktivitas tanaman. Hasil eksplorasi menunjukkan total cendawan (Gambar 2a) dan bakteri (Gambar 2b), dan lahan dengan produktivitas tanaman tinggi memiliki kelimpahan yang tinggi dibandingkan lahan dengan produktivitas tanaman rendah. Akan tetapi, pada kedua produktivitas tanaman tersebut baik kelimpahan cendawan maupun bakteri tidak menunjukkan beda nyata. Lahan dengan produktivitas tanaman tinggi memiliki kesuburan tanah yang lebih baik sehingga menunjang aktivitas mikrob. Dengan adanya aktivitas mikrob maka memengaruhi pertumbuhan tanaman sehingga meningkatkan produktivitasnya (Kniffin \& Balser 2008; Kamaruzzaman et al. 2020).

Akan tetapi, Gambar 2c menunjukkan kelimpahan mikrob fungsional yang berbeda. Lahan dengan produktivitas tanaman rendah mempunyai kelimpahan mikrob fungsional, yaitu bakteri pelarut kalium, Azotobacter, bakteri pelarut fosfat, dan bakteri kitinolitik yang lebih tinggi jika dibandingkan lahan dengan produktivitas tanaman tinggi. Kelimpahan bakteri pelarut kalium dan bakteri kitinolitik tidak menunjukkan beda nyata, sedangkan Azotobacter dan bakteri pelarut fosfat berbeda nyata pada kedua produktivitas tanaman. Tingginya kelimpahan mikrob
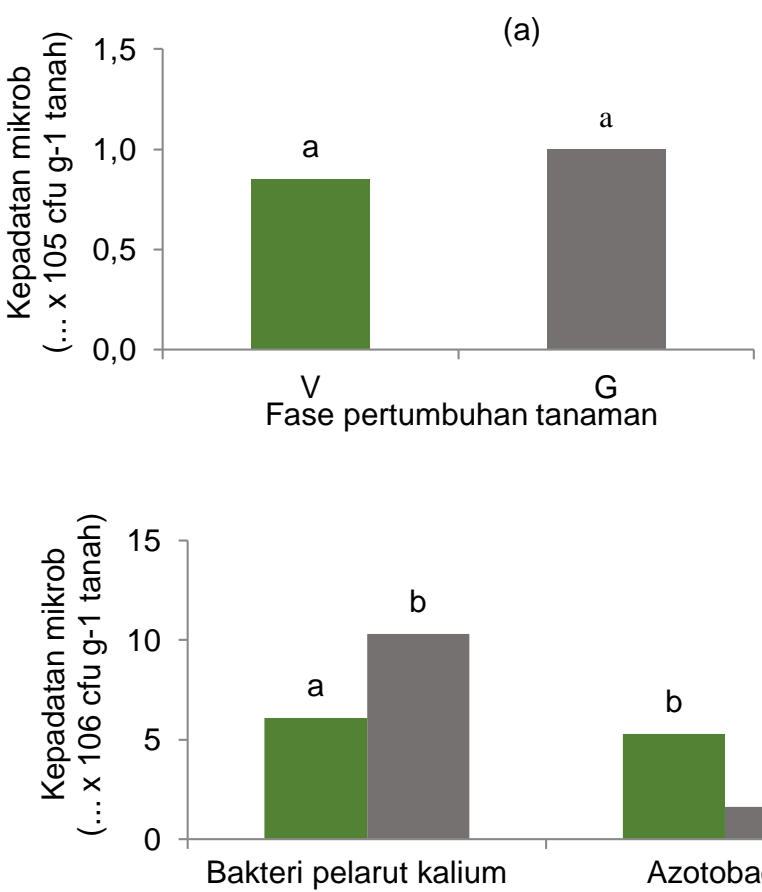

Mikrob fungsiona

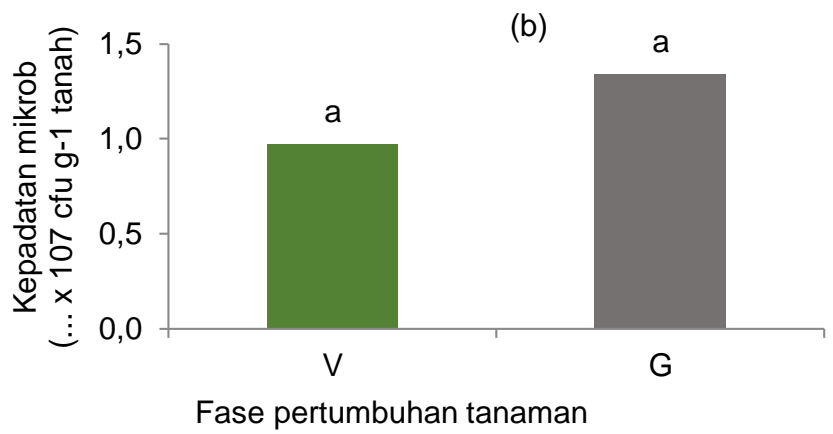

(c)

Gambar 1 Kelimpahan mikrob rizosfer pada fase pertumbuhan tanaman. Grafik yang diikuti huruf yang sama menunjukkan tidak berbeda nyata $V=$ Fase pertumbuhan vegetatif dan $G=$ Fase pertumbuhan generative. a) Cendawan, b) Bakteri, dan c) Fungsional. 

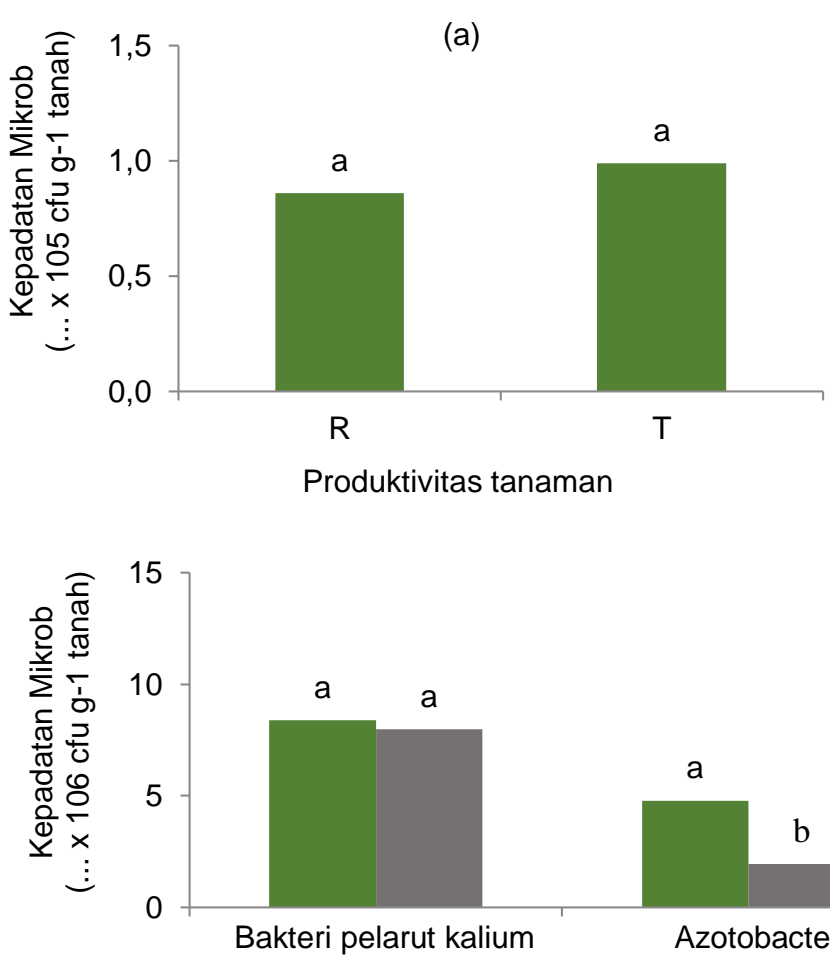

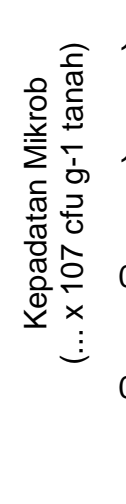

(c)

(b)

a

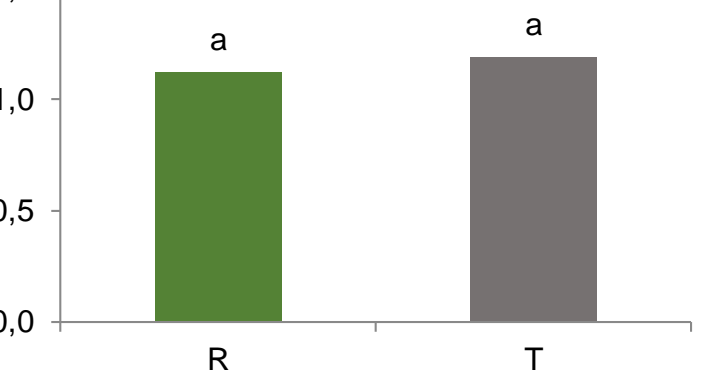

Produktivitas tanaman

) 
(a)

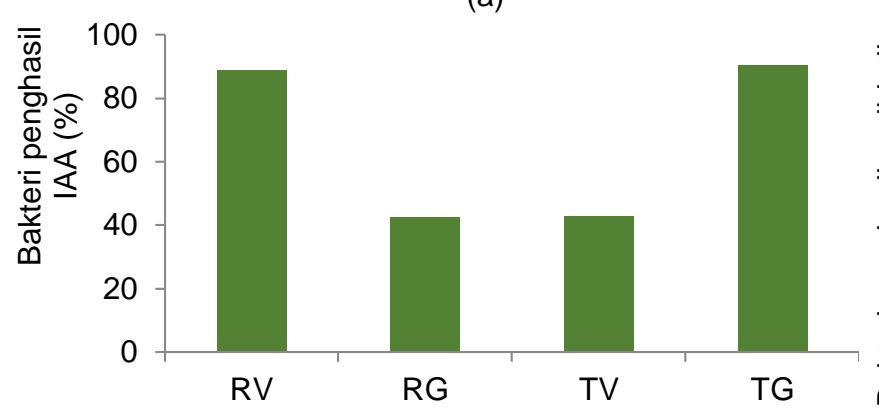

Produktivitas dan fase pertumbuhan tanaman

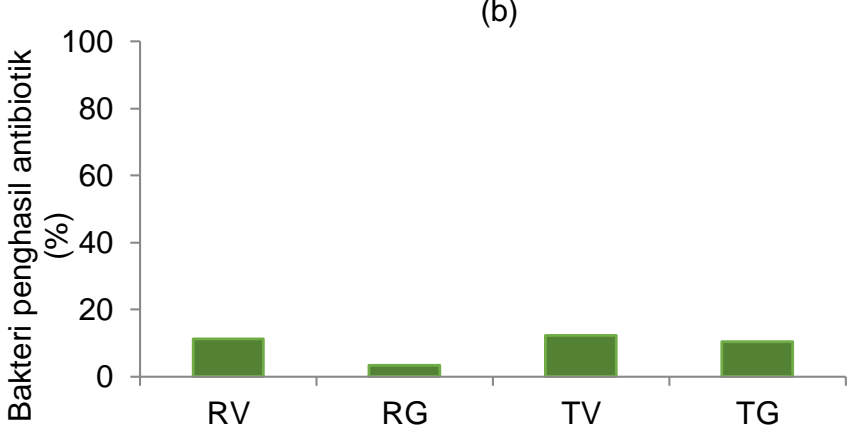

Produktivitas dan fase pertumbuhan tanaman

Gambar 3 Dominansi bakteri penghasil. a) IAA dan b) Antibiotik pada dua tingkat produktivitas tanaman. RV = Produktivitas tanaman rendah fase vegetatif, $R G=$ Produktivitas tanaman rendah fase generatif, $T V=$ Produktivitas tanaman tinggi fase vegetatif, dan $\mathrm{TG}=$ Produktivitas tanaman tinggi fase generatif.

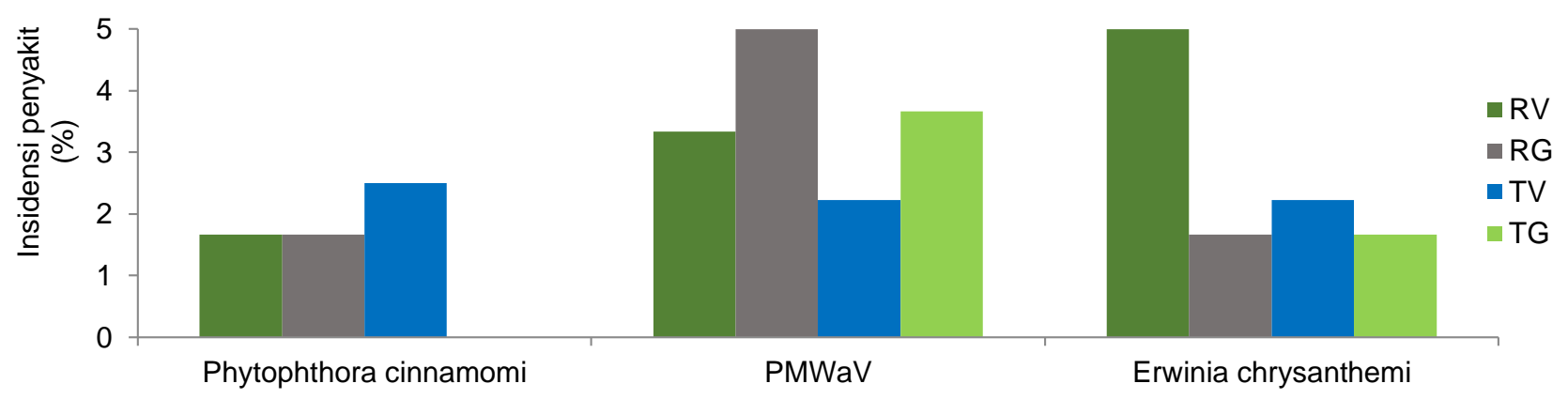

Patogen

Gambar 4 Insidensi penyakit oleh patogen Phytophthora cinnamomi. RV = Produktivitas tanaman rendah fase vegetatif dan $\mathrm{RG}=$ Produktivitas tanaman

rentan terserang patogen. Tanaman yang relatif muda masih belum optimal secara fisiologis sehingga mempengaruhi vigor tanaman.

Pada Gambar 4 dapat dilihat bahwa serangan patogen cenderung tinggi di lahan dengan produktivitas tanaman yang rendah. Hal ini menunjukkan bahwa serangan patogen yang rendah lebih banyak terdapat pada tanah dengan produktivitas tanaman yang tinggi, atau insidensi penyakit utama nanas merupakan indikator penting bagi produktivitas lahan yang ditanami nanas.

\section{Hubungan Insidensi Penyakit dengan Mikrob Fungsional Tanah}

Terdapat keterkaitan antara insidensi penyakit dengan mikrob fungsional rizosfer. Hasil penelitian menunjukkan korelasi antara patogen dengan mikrob fungsional pada fase vegetatif (Tabel 1) dan generatif tanaman (Tabel 2). Pada tanaman yang berada pada fase vegetatif, terdapat korelasi positif antara kelimpahan bakteri pelarut kalium dengan insidensi penyakit layu nanas yang disebabkan oleh PMWaV (Tabel 1). Bakteri pelarut kalium berperan dalam pelarutan kalium sehingga dapat diserap tanaman. Secara umum, kecukupan kalium pada tanaman juga merupakan faktor penentu bagi ketahanan tanaman terhadap hama dan penyakit. Akan tetapi, korelasi positif ini disebabkan oleh pemupukan kalium yang tinggi pada lahan penelitian sehingga peran bakteri pelarut kalium diduga tidak terlalu besar dalam ketersediaan kalium (Bhaduri et al. 2014).

Korelasi negatif juga ditunjukkan antara kelimpahan bakteri kitinolitik dengan insidensi penyakit busuk lunak yang disebabkan oleh Erwinia chrysanthemi (Tabel 1). Degradasi kitin oleh bakteri kitinolitik menghasilkan senyawa antimikrob yang mematikan atau menghambat pertumbuhan bakteri Erwinia chrysanthemi. Salah satu produk hasil penguraian kitin adalah kitosan, yang mempunyai sifat antibacterial dan antifungal (Salama et al. 2020).

Pada fase generatif tanaman (Tabel 2), kelimpahan Azotobacter berkorelasi positif dengan insidensi penyakit layu nanas dan busuk lunak. Azotobacter berperan menambat $\mathrm{N}_{2}$ sehingga memenuhi kebutuhan $\mathrm{N}_{2}$ tanaman. Akan tetapi, kandungan $\mathrm{N}_{2}$ yang cenderung tinggi menyebabkan tanaman rentan terhadap serangan serangga vektor dan patogen. Laporan Hogendorp et al. (2006) menunjukkan bahwa dinding sel tanaman menipis dengan kandungan $\mathrm{N}_{2}$ yang semakin tinggi.

Dominansi bakteri penghasil IAA juga berkorelasi negatif dengan insidensi penyakit busuk hati yang disebabkan oleh Phytophthora cinnamomi (Tabel 2). IAA yang dihasilkan oleh bakteri akan meningkatkan vigor tanaman. Selain itu, produksi IAA oleh bakteri produser berperan penting dalam meningkatkan 
Tabel 1 Korelasi mikrob fungsional tanah dengan patogen nanas pada fase vegetatif

\begin{tabular}{lcccccc}
\hline \multirow{2}{*}{$\begin{array}{c}\text { Tingkat } \\
\text { serangan } \\
\text { patogen }\end{array}$} & \multicolumn{5}{c}{ Koefisien korelasi } \\
\cline { 2 - 7 } & Pelarut kalium & Azotobacter & Pelarut fosfat & Kitinolitik & Penghasil IAA & Penghasil antibiotik \\
\hline Phytophthora & 0,45 & 0,23 & 0,25 & $-0,22$ & 0,17 & 0,47 \\
cinnamomi & $0,50^{*}$ & 0,08 & 0,39 & $-0,09$ & 0,08 & 0,07 \\
$P M W a V$ & $-0,18$ & 0,06 & 0,21 & $-0,52^{*}$ & $-0,12$ & 0,16 \\
Erwinia & chrysanthemi & & & &
\end{tabular}

Keterangan: Angka dalam tabel merupakan nilai korelasi Pearson dengan angka yang diikuti tanda $\left({ }^{*}\right)$ menunjukkan korelas $P<0,1$.

Tabel 2 Korelasi mikrob fungsional tanah dengan patogen nanas pada fase generatif

\begin{tabular}{lcccccc}
\hline \multirow{2}{*}{$\begin{array}{c}\text { Tingkat } \\
\text { serangan } \\
\text { patogen }\end{array}$} & \multicolumn{5}{c}{ Koefisien korelasi } \\
\cline { 2 - 6 } & Pelarut kalium & Azotobacter & Pelarut fosfat & Kitinolitik & Penghasil IAA & Penghasil antibiotik \\
\hline $\begin{array}{l}\text { Phytophthora } \\
\text { cinnamomi }\end{array}$ & $-0,22$ & $-0,15$ & $-0,18$ & $-0,42$ & $-0,53^{*}$ & 0,15 \\
PMWaV & 0,08 & $0,65^{*}$ & 0,11 & 0,20 & 0,10 & 0,40 \\
Erwinia & 0,15 & $0,68^{*}$ & 0,05 & 0,05 & $-0,34$ & $-0,07$ \\
chrysanthemi & 0,10 & &
\end{tabular}

Keterangan: Angka dalam tabel merupakan nilai korelasi pearson dengan angka yang diikuti tanda $\left.{ }^{*}\right)$ menunjukkan korelasi $P<0,1$.

adaptasi tanaman inang terhadap cekaman abiotik (Park et al. 2017). Tanaman dengan vigor yang baik lebih tahan terhadap serangan patogen. IAA selain sebagai fitohormon, memiliki peranan lain, yaitu senyawa antimikrob yang dapat menghambat mikrob patogen (Ahemad \& Kibret 2014).

\section{KESIMPULAN}

Kelimpahan dan keanekaragaman mikrob rizosfer nanas berbeda antara fase vegetatif dan fase generatif pada berbagai tingkat produktivitas. Kelimpahan bakteri pelarut kalium, bakteri kitinolitik, dan bakteri penghasil IAA lebih tinggi pada fase generatif. Kelimpahan Azotobacter, bakteri pelarut fosfat, dan bakteri penghasil antibiotik lebih tinggi pada fase vegetatif pada berbagai tingkat produktivitas tanaman. Kelimpahan total cendawan dan bakteri rizosfer tidak berbeda nyata antarlahan yang mempunyai produktivitas yang berbeda. Lahan yang berproduktivitas tinggi mempunyai kelimpahan bakteri penghasil IAA dan penghasil antibiotik yang lebih tinggi.

Pada fase vegetatif tanaman, kelimpahan bakteri pelarut kalium berkorelasi positif dengan penyakit layu nanas dan kelimpahan bakteri kitinolitik berkorelasi negatif dengan insidensi penyakit busuk lunak. Pada fase generatif tanaman, kelimpahan Azotobacter berkorelasi positif dengan insidensi penyakit layu nanas dan penyakit busuk lunak, dan dominansi bakteri penghasil IAA berkorelasi negatif dengan insidensi penyakit busuk hati.

\section{DAFTAR PUSTAKA}

Adam A, Yusof Y, Yahya A. 2016. Extraction of pineapple leaf fibre: josapine and moris. Journal of Engineering and Applied Sciences. 11(1):161-165.

Ahemad M, Kibret C. 2014. Mechanisms and applications of plant growth promoting rhizobacteria: current perspective. Journal of King Saud University. 26: 1-20. https://doi.org/10. 1016/j.jksus.2013.05.001

Al-Maliki S, Ebreesum H. 2020. Changes in soil carbon mineralization, soil microbes, roots density and soil structure following the application of the arbuscular mycorrhizal fungi and green algae in the arid saline soil. Rhizosphere 14: 1-7. https://doi.org/ 10.1016/j.rhisph.2020.100203

Bhaduri D, Rakshit R, Chakraborty K. 2014. Primary and secondary nutrients-a boon to defense system against plant diseases. Journal of Biological Stress Management. 5(3): 461-466. https://doi.org/ 10.5958/0976-4038.2014.00597.1

Campbell R. 1985. Plant Microbiology. Britain (UK): The Castlefield Press.

Chen ZJ, Tian YH, Zhang Y, Song BR, Li HC. 2016. Effects of root organic exudates on rhizosphere microbes and nutrientremoval in the constructed wetlands. Ecological Engineering. 92: 243-250. https://doi.org/10.1016/j.ecoleng.2016.04.001

Fraser FC, Todman LC, Corstanje R, Deeks LK, Harris JA, Pawlett M. 2016. Distinct respiratory responses 
of soils to complex organic substrate are governed predominantly by soil architecture and its microbial community. Soil Biology and Biochemistry. 103: 493-501. https://doi.org/10.1016/j.soilbio.2016. 09.015

Harahap F, Nusyirwan. 2014. Induksi tunas nanas (Ananas comosus L. Merr) in vitro dengan pemberian dosis auksin dan sitokinin yang berbeda. Jurnal Kesehatan Medika saintika. 15(11): 124-131.

Hogendorp BK, Cloyd RA, Swiader JM 2006. Effect of nitrogen fertility on reproduction and development of citrus mealybug, Planococcus citri Risso (homoptera: Pseudococcidae), feeding on two colors of coleus, Solenostemon scutellarioides L. codd. Environmental Entomology. 35(2): 201-211. https://doi.org/10.1603/0046-225X-35.2.201

Jha CK, Saraf M 2015. Plant growth promoting rhizobacteria (PGPR): a review. Journal of Agricultural Research and Development. 5(2): 108-119.

Jiang Y, Wu Y, Hu N, Li H, Jiao J. 2020. Interactions of bacterial-feeding nematodes and indole-3-acetic acid (IAA)-producing bacteria promotes growth of Arabidopsis thaliana by regulating soil auxin status. Applied Soil Ecology. 147: 1-9. https://doi.org/ 10.1016/ j.apsoil.2019.103447

Kamaruzzaman MA, Abdullah SRS, Hasan HA, Hassan M, Othman AR, Idris M. 2020. Characterisation OF Pb-RESISTANT plant growthpromoting rhizobacteria (PGPR) from Scirpus grossus. Biocatalysis and Agricultural Biotechnology 23. https://doi.org/10.1016/ j.bcab.2019.101456

Kniffin JK, Balser TC. 2008. Soil fertility and the impact of exotic invasion on microbial communities in Hawaiian forests. Microbial Ecology. 56: 55-63. https://doi.org/10.1007/s00248-007-9323-1

Moreno-Salazar R, Sánchez-García I, Chan-Cupul W, Ruiz-Sánchez E, Hernández-Ortega HA, PinedaLucatero J, Figueroa-Chávez D. 2020. Plant growth, foliar nutritional content and fruit yield of Capsicum chinense biofertilized with Purpureocillium lilacinum under greenhouse conditions. Scientia Horticulturae 261: 1-8. https://doi.org/10.1016/ j.scienta.2019.108950

Park Y-G, Mun B-G, Kang S-M, Hussain A, Shahzad R, Seo C-W. 2017. Bacillus aryabhattai SRB02 tolerates oxidative and nitrosative stress and promotes the growth of soybean by modulating the production of phytohormones. PLOS ONE 12(3): 1-28. https://doi.org/10.1371/journal. pone.017320 3

Peng H, de-Bashan LE, Bashan Y, Higgins BT. 2020. Indole-3-acetic acid from Azosprillum brasilense promotes growth in green algae at the expense of energy storage products. Algal Research 47: 1-10. https://doi.org/10.1016/j.algal.2020.101845

Proctor C, He Y. 2017. Quantifying root extracts and exudates of sedge and shrub in relation to root morphology. Soil Biology and Biochemistry. 114: 168-180. https://doi.org/10.1016/j.soilbio.2017. 07.006

Ramli ANM, Manas NHA, Hamid AAA, Hamid H, Illias RM. 2018. Comparative striuctural analysis of fruit and stem bromealin from Ananas comosus. Food Chemistry. 266: 183-191. https://doi.org/ 10.1016/j.foodchem.2018.05.125

Salama A, Hasanin M, Hesemann P. 2020. Synthesis and antimicrobial properties of new chitosan derivatives containing guanidinium groups. Carbohydrate Polymers. 241. https://doi.org/ 10.1016/j.carbpol.2020.116363

Schnitzer SA, Klironomos JN, Hillerislambers J, Kinkel LL, Reich PB, Xiao K, Rillig MC, Sikes BA, Callaway RM, Mangan SA, Van Nes EH, Scheffer M. 2011. Soil microbes drive the classic plant diversityproductivity pattern. Ecology. 92(2): 296-303. https://doi.org/10.1890/10-0773.1

Shazad T, Chenu C, Genet P, Barot S, Perveen N, Mougin C, Fontaine S. 2015. Contribution of exudates, arbuscular mycorrhizal fungi and litterdepositions to the rhizosphere priming effect induced by grasslandspecies. Soil Biology and Biochemistry. 80: 146-155. https://doi.org/10.1016/ j.soilbio.2014.09.023

Sobral JK, Araujo WL, Mendes R, Geraldi IO, Kleiner AAP, Azevedo AL. 2004. Isolation and characterization of soybean associated bacteria and their potential for plant growth promotion. Environmental Microbiology. 6(12): 1244-1251. https://doi.org/10.1111/j.1462-2920.2004.00658.x

Syamsia, Kuswinanti T, Syam'un E, Masniawati A. 2015. The potency of endophytic fungal isolates collected from local aromatic rice as indole acetic acid (IAA) producer. Procedia Food Science. 3: 96-103. https://doi.org/10.1016/j.profoo.2015.01.0 09

Weber OB, Lima RN, Crisostomo LA, Freitas JAD, Carvalho ACPP, Maia AHN. 2009. Effect of diazotrophic bacterium inoculation and organic fertilization on yield champaka pineapple intercropped with irrigated sapota. Plant Soil. 327(1): 355-364. https://doi.org/10.1007/s11104009-0059-1

Yu Z, Pei H, Jiang L, Hou Q, Nie C, Zhang L. 2018. Phytohormone addition coupled with nitrogen depletion almost tripled thelipid productivities in two algae. Bioresource Technology. 247: 904-914. 